\title{
THE INFLUENCE OF SOIL CONSERVATION ON HILL COUNTRY MANAGEMENT
}

\author{
M. KING \\ 1. Chief Soil Conservator, Wairarapa Catchment Board \\ Summary
}

Although the classes of stock may be varied, livestock and timber will remain the basic utilization for the Wairarapa hill oountry. Erosion and a dissected topography have placed restrictions on stock, and thus pasture control, limiting production attainment and accelerating erosion.

The, application of soil conservation methods designed initially to facilitate erosion control and enable catchment and aspect subdivision have overcome many of the past difficulties. With intensive pasture control now possible, much more effective use can be made of steep, broken hill country and towards this end further study is urged with pasture species to meet the special needs of this area.

\section{INTRODUCTION}

Aттноиян the methods and practices reported here are largely concerned with the Wairarapa East Coast Hill Country, they may have wide application throughout New Zealand. Gibbs (1963), has stated that instability is a severe limitation to the use of $26,000,000$ acres, which is $40 \%$ of the New Zealand land area.

The Wairarapa east coast area extends from the Akitio River in the North to Palliser Bay and consists of very dissected hill country, mainly below $1,500 \mathrm{ft}$ but rising to $3,000 \mathrm{ft}$ in the Aorangi Range. Part of it drains west into the Manawatu and the Ruamahanga Rivers, while the remainder is in a series of smaller catchments draining directly to the east coast. The predominant rock formations are mudstone, argillite and sandstone with limited areas of greywacke. Soils derived from the two former rocks predominate and are characterized by wide-spread erosion problems (Gibbs, 1964) .

Erosion and management problems are aggravated by a variable rainfall, often in the 40 to $55 \mathrm{in}$. range but with some areas in the low 30s giving frequent summer drought periods and periodic, high-intensity, damaging storms. The summer water deficiency is aggravated by the prevailing north-west wind. 
Land suitable for cropping occupies a small percentage of the area and most hill farms have little or no scope for this form of diversification. Forestry now occupies 34,000 acres of formerly reverted country and this area will probably be expanded substantially in the future. Meanwhile, most farm units must rely largely on wool and store stock production with an increasing proportion of stock being fattened as the country is improved. More intensive use with higher stocking rates and corresponding capital investment is focusing greater attention on soil and water conservation and exposing the difficulties of effectively developing steep, broken hill country.

\section{EROSION}

Apart from soil loss by sheet erosion, the most common and troublesome erosion form is down-cutting and gully erosion in water-courses, with subsequent slope instability typified by massive slump movements, lateral gullying and slip movements. The consequences of this damage are channels choked by debris, impaired drainage; increased flooding, and a deterioration of stream flow as a source of water.

In the weak rock materials mentioned, -this erosion cycle results from increased run-off and the removal of rough protective vegetation from water-courses and steep slopes on a topography originally stabilized under a forest cover.

\section{EFFECT ON MANAGEMENT}

Active erosion of this type effects management and production on a hill country farm in a number of ways, for example:

(1) Loss of topsoil and fertility reduce pasture production.

(2) Actual area of pasture is reduced.

(3) Soil drainage and structure are impaired by movement with lowered production from the resultant inferior pasture species.

(4) Natural stock water is deteriorated both in quality and quantity.

(5) Stock losses can be high in muddy streams, slips and gullies.

(6) Valley floors are silted and wet, restricting production and again down-grading pasture species. 
(7) Fences, tracks, buildings, domestic and stock water supply installations are damaged and destroyed.

(8) Stock and labour movement, and access are complicated and restricted.

(9) Development plans for fencing, tracking, pasture improvement and cultivation are restricted.

\section{PRINCIPLES OF CONTROL}

The normal approach to gully control or prevention follows these principles:

(1) Reduce and regulate run-off rates.

(2) Protect water-courses and retard stream flow.

(3) Reinforce steep unstable slopes by toe protection and the use of trees.

(4) Retain erosion debris near its source.

(5) Revegetate eroded surfaces.

(6) Apply management which will ensure high, sustained production according to land capability determinations.

\section{APPLICATION OF SOIL CONSERVATION PRACTICES}

Vegetation and stock control are clearly the principal factors which can be manipulated to influence the water movement and soil stability. Soil changes can be induced over a longer period or will follow quickly any deterioration of the cover.

Erosion in the past has been a major impediment to subdivision and controlled grazing, and so treatment of existing erosion damage frequently must precede refined work on run-off reduction on steep hill country where mechanical means (such as contour and control structures) are impractical. The usual approach to erosion control in water-courses and gullies in this district, when dealing with severe damage, has ranged from fencing and intensive tree planting aided by structures to give primary stability, to relatively light unfenced tree planting with or without structures, or small protected tree blocks at key sites.

It was quickly seen as these treated areas consolidated that, far from reducing carrying capacity and being an impediment to the concept of clear grassland favoured by many, the trees and structures in fact provided the key to fencing and thus presented 
a practical means of achieving aspect and catchment subdivision.

The deleterious effects of selective grazing and stock preference for sunny faces have long been recognized (Lamont, 1939; Hamblyn, 1954) but are only partially overcome by mob-stock grazing. Even with really high grazing intensities, full, even utilization is difficult to obtain (Suckling, 1964) and this certainly cannot be done on steep country with aspect extremes, without adversely affecting the preferred country at critical periods.

Because of these factors, differential use of pasture species to suit the widely differing site conditions contained in typical paddocks or blocks has not been a practical proposition. Desirable species, particularly suited to dry faces for example, have not been able to succeed, and have been replaced by inferior grasses such as danthonia, browntop and poa with low productivity. This is the sward type which gives high rates of run-off, poor surface detention and infiltration, thus perpetuating low productivity. With an open danthonia-type sward, sheet erosion is inevitable and results in further deterioration.

Conversely, soil and pasture damage by heavy stocking, particularly with cattle on wet slopes during winter, is frequently the cause of low productivity, weed invasion, increased run-off and erosion. Shady country will not be adequately grazed if stock have free access to a balance of preferred country.

To meet this type of situation, erosion control techniques have been adapted to facilitate subdivision to the following patterns.

(1) Subdivision of aspects when these significantly affect soil loss, run-off and/or production.

(2) Subdivision of catchment basins, to make regulations of run-off compatible with efficient pasture utilization, through mob-stock grazing and preferential paddock treatment.

Gully fencing and tree planting were quickly found to allow subdivision of many areas to meet conservation requirements. "Live fencing" - i.e., the use of trees to support a wire fence was developed by Pearce (1962) and other workers and has a definite place on gully bottoms and unstable slopes. Small debris dams have been modified to produce stable fence and stock crossings and can be designed to incorporate a floodgate, thus greatly improving this most troublesome part of the hill country fence. Figure 1 shows a typical example of a catchment with aspects separated and paddocks increased from two to eight using these methods. 


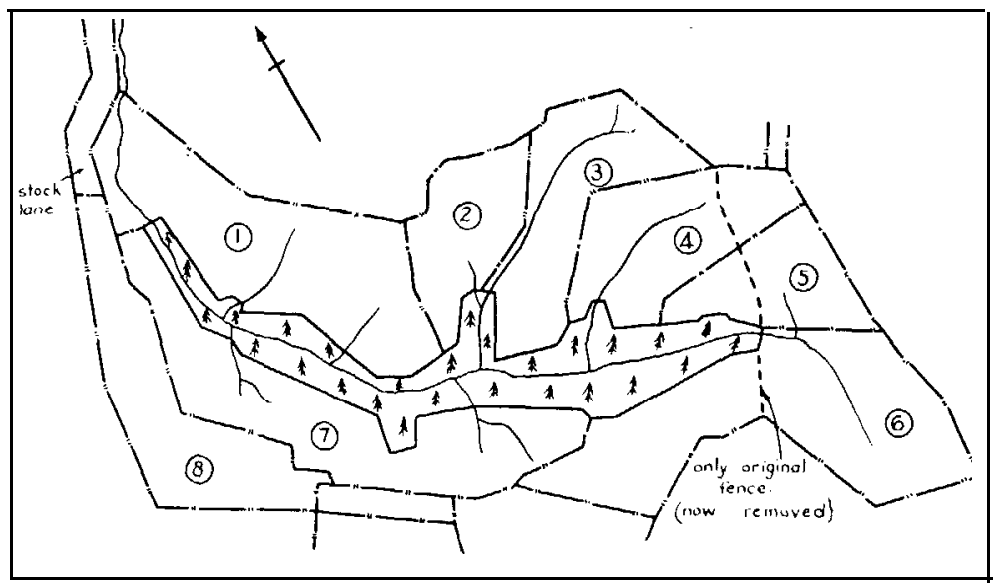

Fig. 1: Blairlogie catchment and aspect subdivision.

In wider, aggraded stream beds, groynes and a cóntrolled drop structure are employed to restrict stream width and provide a stable site for fence and floodgate crossings, The "Soil Conservation" type post and wire fence (Pearce and Humphries, 1965) has made possible considerable economy in fence erection and a combination of netting, trees and structures has made fencing practical on country where by traditional means few lines could be considered away from stable ridge tops.

A further refinement to give greater flexibility and aid stock movement has been the adaptation of the dairy farm "stock race" system to hill country. In its simplest form, it consists of the odd narrow paddock to by-pass other blocks, while more sophisticated lay-outs give direct access to most paddocks and usually incorporate an all-weather track. This enables greater paddock discrimination and significantly reduces the labour requirement for stock movement.

The development of the cattle pad and other intensive systems of winter cattle management have (in part) developed because of soil and pasture damage on hill country and are a further aid to preferential paddock treatment. On heavy, wet, steep mudstone soils, for example, cattle damage during winter can be severe, influencing not only pasture composition and production but also in some circumstances predisposing a cycle of erosion. Grazing cattle and sheep separately on hill country may also help combine soil conservation requirements with high production. 


\section{FUTURE PASTURES}

Micro-climatic conditions vary tremendously in typical east coast hill country, and in some situations protection can be a more important consideration than production. Under normal management on steep country these special requirements can rarely be met, with the result that ryegrass, white clover and subterranean clover have generally been recommended exclusively for almost all North Island hill country.

Ryegrass and white clover, excellent though they are on suitable country, will not persist or remain productive on the moisture-deficient north-west faces, especially on the argillite and similar soils (Mitchell, 1954). Subterranean clover, being an annual, has disadvantages from the protection viewpoint but the other grasses which seemed more likely to meet these site requirements have not stood up to the hard, close grazing previously unavoidable. Similarly, shady or wet country in this type of paddock situation is frequently unable to reach its potential:

There is a large area of land to which this applies and it is suggested that studies could profitably be intensified along the following lines to investigate:

(1) Methods of introducing grasses and le'gumes to existing swards.

(2) Whether grasses of the cocksfoot-phalaris type are more productive than ryegrass on this country.

(3) Methods of management of these species to give high production and maximum protection.

(4) The potential of various perennial legumes grown in association with these grasses.

(5) Plants of the pampas type or edible shrubs which can play a protective role in water-courses and gullies and provide an emergency ration in times of feed shortage - e.g., drought or a prolonged winter.

The major obstacle to the specialized use of pastures on hill country has always been inability to control grazing and it is now suggested that the development of the subdivision techniques outlined in this paper go much of the way towards overcoming this aspect of the problem. If this is followed by the pasture investigations suggested, much more effective utilization of steeper hill country will be possible. 


\section{REFERENCES}

Gibbs, H. S., 1963: Proc. N.z. Inst. agric. Sci., 9: 63-79. , 1964: Proc. N.Z. Inst. agric. Sci., 10: 61-7.

Hamblyn, C. J., 1954: Proc. N.z. Grassld Ass., 16: 132-9.

Lamont, N., 1939: N.Z. Il Agric., 59: 211-7.

Mitchell, K. J., 1954: Proc. N.Z. Grassld Ass., 16:. 75-81.

Pearce, H. C. H., 1962: N.Z. Il Agric., 104 (2) : 123-5.

Pearce, H. C. H.; Humphries, K. R., 1965: Bull. Dept Agric. N.Z.

Suckling, F. E. I'., 1964: Proc. N.Z. Grassld Ass., 26: 137-52.

\section{DISCUSSION}

To a question on the use of fertilizers to aid tree planting, King stated that none were used except on some argillite soils where it had been found that nitrogen had improved the growth of poplars.

Concerning co-ordination with departments carrying out large-scale land development, he said that there was little such work being carried out in the Wairarapa but, in other areas, there was excellent collaboration between land development and soil conservation people.

Manuka was of little use as a conservation plant. It was shallowrooted, and had a greasy leaf fall which shed water very rapidly. In some areas it was left only as a temporary measure to be replaced eventually by more suitable trees.

Pines were particularly useful in drier, windy sites. Where they could be utilized and trimmed, there was no difficulty in maintaining grass cover. In more difficult areas, wider spacing was necessary to enable grass to grow under the trees. Acacias could also be useful as they were legumes and also suckered well.

To a suggestion that smaller species such as shrubs might be used to gain stability above gully heads, King replied that they could be useful but only in the absence of stock. As yet no really satisfactory tree had been found for such areas.

He thought the combination of cattle feed-lots with soil conservation measures was a most desirable end result. As the idea of grazing cattle and sheep separately spread, he felt that this would become more common. In fact, soil conservation plans were already helping to bring it about. 